\title{
PERAN NOTARIS DALAM PENEGAKAN HAK ASASI MANUSIA
}

\author{
Susani Triwahyuningsih \\ Universitas Merdeka Ponorogo \\ Jl. Pacar No. 35 Tonatan Ponorogo \\ Email: susanitri@gmail.com
}

\begin{abstract}
Abstrak
Notaris merupakan salah satu pelayan masyarakat yang penting atau bahkan istimewa. Pelayanannya ini berhubungan dengan perlindungan atau penegakan hukum. Dalam ranah demikian, peran yang dilakukan oleh notaris identik dengan menegakkan hak asasi manusia (HAM), karena dari aktifitas yang dilakukannya dapat memberikan jaminan kepastian yuridis terdapa hak-hak masyarakat atau pihak yang meminta jasa layanan kepadanya. Kalau jasa layanan yang ditunjukkannya benar sesuai dengan norma yuridis, maka hal ini memosisikannya sebagai subyek yang bekomitmen terhadap HAM.
\end{abstract}

Kata kunci: notaris, peran, hak asasi manusia, penegakan

\section{Abstract}

Notary is one of important or even special public servants. This service is related to protection or law enforcement. In this domain, the role carried out by the notary is synonymous with upholding human rights (HAM), because the activities carried out can provide a guarantee of juridical certainty on the rights of the society or the party requesting services to him. If the services shown are in accordance with juridical norms, then their positions as subjects who are committed to HAM.

Keywords: notary, role, human rights, enforcement

\section{PENDAHULUAN}

"Kendati kapal akan karam, tegakkan hukum dan keadilan", Pesan Baharudin Lopa itu sejatinya mengingatkan setiap pejuang hukum dan keadilan, bahwa di tangan atau pundaknya, ada HAM yang harus diperjuangkan dengan segenap jiwa raga. Tidak bole mengenal kata surut, apalagi mundur untuk melindungi atau menegakkan HAM. ${ }^{1}$

Diskursus tentang HAM memang sangat beragam. Akan tetapi secara general setiap orang tentu sepakat mengakui, bahwa setiap manusia itu mempunyai sejumlah hak yang harus dilindungi oleh orang lain,

\footnotetext{
${ }^{1}$ Abdul Wahid, Ana Rokhmatussa'diyah, Anang Sulistyono, Desperatus Perlindungan HAM, (Jakarta: Nirmana Media, 2017), hal. 1
} 
termasuk para pihak yang berurusan dengan notaris. Dalam UndangUndang Nomor 39 Tahun 1999 tentang Hak Asasi Manusia disebutkan, bahwa Hak Asasi Manusia adalah seperangkat hak yang melekat pada hakikat dan keberadaan manusia sebagai makhluk Tuhan Yang Maha Esa dan merupakan anugerahNya yang wajib dihormati, dijunjung tinggi dan dilindungi oleh negara, hukum dan Pemerintah, dan setiap orang demi kehormatan serta perlindungan harkat dan martabat manusia (Pasal 1 angka 1).

Austin-Ranney juga berpendapat, bahwa HAM adalah ruang kebebasan individu yang dirumuskan secara jelas dalam konstitusi dan dijamin pelaksanaannya oleh pemerintah. Pemerintah memberikan jaminan terhadap terlaksana tidaknya HAM. A.J.M. Milne menyebut, bahwa HAM adalah hak yang dimiliki oleh semua umat manusia di segala masa dan di segala tempat (wilayah, daerah, bangsa, negara, atau dimanapun seseorang berhubungan atau beraktifitas) karena keutamaan keberadaannya sebagai manusia, ${ }^{2}$ sehingga saat berhubungan dengan notaris pun, seseorang yang menghadapnya mestilah membawa HAM.

Dalam pandangan lain disebutkan oleh John Locke. Menurut John Locke, hak asasi adalah hak yang diberikan langsung oleh Tuhan sebagai sesuatu yang bersifat kodrati. Artinya, hak yang dimiliki manusia menurut kodratnya tidak dapat dipisahkan dari hakikatnya, sehingga sifatnya suci. ${ }^{3}$

Hal itu menunjukkan, bahwa manusia pada hakikatnya telah mempunyai atau diaugerahi hak dan kewajiban. Tiap manusia mempunyai hak dan kewajiban yang berbeda, tergantung pada misalnya, jabatan atau kedudukan dalam masyarakat atau ditentukan oleh peran yang ditentukan dalam norma yang mengaturnya. Masing-masing kalangan profesional di bidang hukum pun demikian, mereka mempunyai hak dan terikat pada kewajiban untuk menegakkan atau melindungi HAM, termasuk Notaris. Masalahnya apakah Notaris memahami dan menyadari kalua dirinya adalah penegak HAM?

\section{PEMBAHASAN}

\section{Notaris dan Akta Autentik}

Kata notaris berasal dari kata "nota literaria" yaitu tanda tulisan atau karakter yang dipergunakan untuk menuliskan atau menggambarkan 
ungkapan kalimat yang disampaikan nara sumber. Tanda atau karakter yang dimaksud adalah tanda yang dipakai dalam penulisan cepat (stenografie). ${ }^{4}$

Pada awalnya jabatan notaris hakikatnya adalah sebagai pejabat umum (private notary) yang ditugaskan oleh kekuasaan umum untuk melayani kebutuhan masyarakat akan alat bukti otentik yang memberikan kepastian hubungan hukum keperdataan. Jadi, sepanjang alat bukti otentik tetap diperlukan oleh sistem hukum negara maka jabatan notaris akan tetap diperlukan eksistensinya di tengah masyarakat.

Notaris seperti yang dikenal di zaman "Republik der Verenigde Nederlanden" mulai masuk di Indonesia pada permulaan abad ke-17 dengan beradanya "Oost Ind. Compagnie" di Indonesia. ${ }^{5}$

Dalam ranah historis perlu dipahami, bahwa setidanya pada tanggal 27 Agustus 1620, yaitu beberapa bulan setelah dijadikannya Jacatra sebagai ibukota (tanggal 4 Maret 1621 dinamakan "Batavia"), Melchior Kerchem, Sekretaris dari "College van Schepenen" di Jacatra, diangkat sebagai Notaris pertama di Indonesia. Di dalam akta pengangkatan Melchior Kerchem sebagai Notaris sekaligus secara singkat dimuat suatu instruksi yang menguraikan bidang pekerjaan dan wewenangnya, yakni untuk menjalankan tugas jabatannya di kota Jacatra untuk kepentingan (pelayanan) publik. Kepadanya ditugaskan untuk menjalankan pekerjaannya itu sesuai dengan sumpah setia yang diucapkannya pada waktu pengangkatannya di hadapan Baljuw di Kasteel Batavia.

Deskripsi itu menunjukkan, bahwa Notaris itu mempunyai pekerjaan dalam hubungannya dengan sisi pemenuhan kebutuhan keamnusianya, sehingga dalam sejarah perkembangan profesi Notaris, identic dengan membahas karier aau pekerjaan. Abdul Wahid, dkk menyebut, bahwa dalam hidup ini manusia, termasuk otaris membutuhkan pekerjaan. Dengan pekerjaan yang dilaksanaan, manusia dapat memenuhi berbagai kebutuhan hidupnya. Sebab, dari pekerjaan yang dilakukan itu, manusia mendapatkan penghasilan. Sebagai hak manusia, maka pekerjaan dapat menentukan penghasilan. Sedangkan penghasilan ini juga menjadi hal yang harus dimilikinya setelah menjalankan pekerjaan. ${ }^{6}$

Notaris adalah pejabat umum yang satu-satunya berwenang untuk membuat akta otentik mengenai semua perbuatan, perjanjian dan penetapan yang diharuskan oleh suatu peraturan umum atau oleh yang berkepentingan dikehendaki untuk dinyatakan dalam suatu akta otentik, menjamin kepastian

${ }^{4}$ G.H.S. Lumban Tobing, Peraturan Jabatan Notaris (Notaris Reglement), (Jakarta: Erlangga, 1980), hal. 41

${ }^{5}$ Ibid, hal. 15

${ }^{6}$ Abdul Wahid, Sunardi, Mariyadi, Penegakan Kode Etik Profesi Notaris. (Jakarta: Nirmana Media, 2017), hal. 56. 
tanggalnya, menyimpan aktanya dan memberikan grosse, salinan dan kutipannya, semuanya sepanjang pembuatan akta itu oleh suatu peraturan umum tidak juga ditugaskan atau dikecualikan kepada pejabat atau orang lain. ${ }^{7}$

Dalam Pasal 1 ayat (1) Peraturan Menteri Hukum dan Hak Asasi Manusia RI No. M.01-HT.03.01 Tahun 2006, tentang Syarat dan Tata Cara Pengangkatan dan Pemindahan, dan Pemberhentian Notaris yang dimaksud dengan Notaris adalah pejabat umum yang berwenang untuk membuat akta otentik dan kewenangan lainnya, sebagaimana dimaksud dalam UndangUndang Jabatan Notaris.

Berdasarkan pengertian-pengertian Notaris diatas ada hal penting yang tersirat, yaitu ketentuan dalam permulaan pasal tersebut, bahwa Notaris adalah pejabat umum dimana kewenangannya atau kewajibannya yang utama ialah membuat akta-akta otentik, jadi Notaris merupakan pejabat umum sebagaimana yang dimaksud pada Pasal 1868 KUHPerdata.

Pengertian Notaris Menurut Pasal 1 Undang-Undang No. 30 Tahun 2004 tentang Jabatan Notaris disebutkan bahwa Notaris adalah pejabat umum yang berwenang untuk membuat akta otentik dan kewenangan lainnya sebagaimana dimaksud dalam Undang-Undang ini.

Dalam UUJN yang diubah, pengertian Notaris adalah perubahan. Dalam Pasal 1 angka 1 Undang-Undang Republik Indonesia Nomor 2 Tahun 2014 Tentangperubahan Atas Undang-Undang Nomor 30 Tahun 2004 Tentang Jabatan Notaris disebutkan Notaris adalah pejabat umum yang berwenang untuk membuat akta autentik dan memiliki kewenangan lainnya sebagaimana dimaksud dalam Undang-Undang ini atau berdasarkan undang-undang lainnya.

Dari sisi komparasi terdapat perbedaan antara pengertian Notaris dalam Undang-Undang Republik Indonesia Nomor 2 Tahun 2014 Dengan Undang-Undang Nomor 30 Tahun 2004 Tentang Jabatan Notaris, yakni kalau dalam UUJN yang lama, kewenangan Notaris hanya disebut dalam UUJN, sedangkan dalam UUJN Perubahan diperluas dengan yang diatur dalam UU lainnya. Khusus dalam kaitannya dengan pembuatan akta autentik, juga ada perubahan kata dari "otentik" menjadi autentik.

Pasal 1868 KUHPerdata menyebutkan: "Eene authentieke acte is de zoodanige welke in de wettelijken vorn is verleden, door of ten overstaan van openbare ambtenaren die daartoe bevoegd zijn ter plaatse alwaar zuiks is geschied." (Suatu akta otentik ialah suatu akta yang dibuat dalam bentuk yang ditentukan undang-undang oleh atau di hadapan pejabat umum yang berwenang untuk itu di tempat akta itu dibuat).

${ }^{7}$ G.H.S. Lumban Tobing, Op. Cit. hal.31 
Openbare Ambtenaren yang diterjemahkan sebagai Pejabat Umum diartikan sebagai pejabat yang diserahi tugas untuk membuat akta otentik yang melayani kepentingan publik, dan kualifikasi seperti itu diberikan kepada Notaris. Maka berdasarkan ketentuan Pasal 1868 Kitab UndangUndang Hukum Perdata tersebut, untuk dapat membuat suatu akta otentik seseorang harus mempunyai kedudukan sebagai pejabat umum. Namun dalam Pasal 1868 itu tidak menjelaskan lebih lanjut mengenai siapa yang dimaksud sebagai pejabat umum tersebut.

Menurut kamus hukum salah satu arti dari Ambtenaren adalah Pejabat. Dengan demikian Openbare Ambtenaren adalah pejabat yang mempunyai tugas yang bertalian dengan kepentingan publik, sehingga tepat jika Openbare Ambtenaren diartikan sebagai Pejabat Publik. Khusus berkaitan dengan Openbare Ambtenaren yang diterjemahkan sebagai Pejabat Umum diartikan sebagai pejabat yang diserahi tugas untuk membuat akta otentik yang melayani kepentingan publik, dan kualifikasi seperti itu diberikan kepada Notaris.

Akta Notaris yang diterbitkan oleh notaris memberikan kepastian hukum bagi masyarakat. Menurut Nusyirwan Notaris adalah orang semi swasta, karena ia tidak bisa bertindak bebas sebagaimana seorang swasta. Ia harus menjunjung tinggi martabatnya, oleh karena itu ia diperkenankan menerima uang jasa (honorarium) untuk setiap pelayanan yang diberikannya. ${ }^{8}$

"Honorarium" berasal dan kata latin Honor yang artinya kehormatan, kemuliaan, tanda hormat/penghargaan semula mengandung pengertian balas jasa para nasabah atau klien kepada dokter, akuntan, pengacara, dan Notaris. ${ }^{9}$ Balas jasa ini yang diterima Notaris dari penghadap atau pemohon jasa merpakan konsekuensi dari pekerjaan yang dilakukannya, sehingga kalau ada penghadap atau pemohon jasa yang tidak memberikan honorarium sebagaimana dalam kesepakatan, maka hak Notaris yang dilanggar, artinya penghadap dapat dikategorikan melakukan pelanggaran HAM.

\section{Penegakan HAM}

Undang-Undang Republik Indonesia Nomor 2 Tahun 2014 Tentang Perubahan Atas Undang-Undang Nomor 30 Tahun 2004 Tentang Jabatan Notaris merupakan produk legislalatif yang menunjukkan, bahwa pembaruan hukum yang dilakukan oleh negara, khususnya yang mengatur 2000), hal 3-4

${ }^{8}$ Nusyirwan, Membedah Profesi Notaris, (Bandung: Universitas Padjadjaran,

${ }^{9}$ Ensiklopedi Nasional Indonesia, (Jakarta: Delta Pamungkas, 2004), hal 472, 
Notaris adalah berkaitan dengan kepentingan pemenuhan hak-hak masyarakat dan dunia hukum.

Norma hukum dibutuhkan untuk mengatur hubungan kehidupan bermasyarakat dan bernegara. Dalam hubungan yang dibangun oleh setiap orang atau pihak, ditentukan oleh norma yang mengaturnya. Norma yang mengatur ini menjadi pijakan kepastian bersikap dan berperilakunya.

Dalam Penjelasan Undang-Undang Republik Indonesia Nomor 2 Tahun 2014 Tentang Perubahan Atas Undang-Undang Nomor 30 Tahun 2004 Tentang Jabatan Notaris disebutkan, bahwa Negara Republik Indonesia sebagai negara hukum berdasarkan Pancasila dan UndangUndang Dasar Negara Republik Indonesia Tahun 1945 menjamin kepastian, ketertiban, dan perlindungan hukum bagi setiap warga negara. Untuk menjamin kepastian, ketertiban, dan perlindungan hukum dibutuhkan alat bukti tertulis yang bersifat autentik mengenai perbuatan, perjanjian, penetapan, dan peristiwa hukum yang dibuat di hadapan atau oleh Notaris. Notaris sebagai pejabat umum yang menjalankan profesi dalam memberikan jasa hukum kepada masyarakat, perlu mendapatkan perlindungan dan jaminan demi tercapainya kepastian hukum. Jaminan perlindungan dan jaminan tercapainya kepastian hukum terhadap pelaksanaan tugas Notaris telah diatur dalam Undang-Undang Nomor 30 Tahun 2004 tentang Jabatan Notaris. Namun, beberapa ketentuan dalam Undang-Undang tersebut sudah tidak sesuai lagi dengan perkembangan hukum dan kebutuhan masyarakat sehingga perlu dilakukan perubahan, yang juga dimaksudkan untuk lebih menegaskan dan memantapkan tugas, fungsi, dan kewenangan Notaris sebagai pejabat yang menjalankan pelayanan publik, sekaligus sinkronisasi dengan undang-undang lain.

Thomas Hobbes dalam "Leviathan" menyebut hukum adalah perintah-perintah dari orang yang memiliki kekuasaan untuk memerintah dan memaksakan perintahnya kepada orang lain, Rudolf von Jhering dalam "Der Zweck Im Recht" 1877-1882 menyebut hukum adalah keseluruhan peraturan yang memaksa yang berlaku dalam suatu negara. Plato berpendapat hukum merupakan peraturan-peraturan yang teratur dan tersusun baik yang mengikat masyarakat. Aristoteles berpendapat, bahwa hukum hanya sebagai kumpulan peraturan yang tidak hanya mengikat masyarakat tetapi juga pihak-pihak yang memahami hukum, diantaranya Notaris. Abdulkadir Muhammad menyatakan hukum adalah segala peraturan tertulis dan tidak tertulis yang mempunyai sanksi yang tegas terhadap pelanggarnya. ${ }^{10}$

${ }^{10}$ Ahmadi Saleh, Menjaga Martabat Profesi Hukum, (Bandung: Cerdas Ilmu, 
Pakar hukum internasional Mochtar Kusumaatmadja berpendapat, bahwa pemahaman hukum yang memadai harus tidak hanya memandang hukum itu sebagai suatu perangkat kaidah dan asas-asas yang mengatur kehidupan manusia dalam masyarakat, tapi harus pula mencakup lembaga (institusi) dan proses yang diperlukan untuk mewujudkan hukum itu dalam kenyataan. ${ }^{11}$ Mewujudkan hukum dalam kenyataan berarti memenuhi apa yang diperintahkan hukum. Ketika yang diperuntahkan oleh hukum ini adalah notaris, berarti peran mulia dilaksanakannya dalam rangka mewujudkan HAM dari ide-ide menjadi kenyataan.

Dalam sebuah teori sistem dikatakan bahwa regulasi/norma/hukum adalah faktor utama yang menentukan baik dan tidaknya manusia. Manusia yang tidak baik jika dimasukkan dalam sebuah sistem yang baik maka hampir dapat dipastikan ia akan menjadi baik. Sebaliknya, sekalipun manusia tersebut baik secara personal, saleh secara individual, tetapi ketika ia ditempatkan dalam sebuah sistem atau lingkungan yang tidak baik, maka ia pun akan menjadi tidak baik. Konsep demikian inilah yang kemudian seperti mendapatkan legitimasinya sebagaimana yang dikemukakan oleh Bordiew sebagai "habitus". ${ }^{12}$

Negara membuat norma yuridis untuk kepentingan pergaulan manusia dalam hubungannya dengan manusia lain. Meski demikian, ada beberapa pendapat mengenai hukum yang antara sarjana satu dengan lainnya tidak sama. Perbedaan ini logis sebagai bukti progresifitas Iptek. Namun demikian, tetap di kalangan ahli atau pemikir hukum sepakat bahwa kehadiran norma yuridis, diantaraya berurusan dengan implementasi kewajiban dan penegakan (perlindungan) hak (HAM).

Tiap manusia mempunyai sifat, watak, dan kehendak sendiri-sendiri. Namun di dalam masyarakat manusia mengadakan hubungan antara yang satu dengan lainnya, mengadakan kerjasama, tolong menolong, Bantu membantu, dan lainnya untuk memperoleh keperluan hidupnya. Keperluan atau kepentingan manusia kadang-kadang baru bisa dipenuhi oleh manusia lainnya Peran manusia lain akan menjadikan terjadinya hubungan sosial yang lebih baik dan saling menguntungkan. ${ }^{13}$

${ }^{11}$ DPD-Universitas Brawijaya, penelitian “Konstruksi Perwakilan Daerah Dalam Sistem Ketatanegaraan Indonesia", Kerjasama DPD RI dan Universitas Brawijaya, , (Malang, Pusat Pengkajian Konstitusi Fakultas Hukum Universitas Brawijaya, 2009), hal. 15.

${ }^{12}$ Ahmad Zainuri, Gorontalo Butuh Regulasi Kos-kosan, http://www.kompasiana.com/ahmad_zaenuri/gorontalo-butuh-regulasi-koskosan_54f34caa7455139f2b6c6f95, akses 15 Juli 2019.

13 CST. Kansil, Pengantar Hukum dan Tata Hukum Indonesia, (Jakarta: Djambatan, 2000), hal. 33. 
Idealisme hukum adalah mengatur pergaulan hidup secara damai. ${ }^{14}$ Dalam setiap kehidupan manusia sebagai mahluk sosial akan selalu berinteraksi dengan manusia yang lain. Dengan adanya interaksi ini akan timbul kepentingan perseorangan dan kepentingan golongan yang kadang menimbulkan pertikaian, akan tetapi dengan interaksi juga memberikan manfaat dengan menambah pengetahuan serta informasi lainnya.

Menurut Satjipto Rahardjo, ${ }^{15}$ bahwa norma hukum adalah sarana yang dipakai oleh masyarakat untuk mengarahkan tingkah laku anggota masyaakat pada saat mereka berhubungan antara yang satu dengan lainnya. Apabila di sini disinggung tentang "mengarahkan tingkah laku", barang tentu pertanyaan dalam diri kita, "mengarahkan kemana"? ke mana norma itu mengarahkan tingkah laku manusia merupakan prioritas yang ada pada masyarakat sendiri. Masyarakatlah yang menentukan arah-arah tersebut dan oleh karena itu kita bisa melihat norma itu sebagai pencerminan dari kehendak masyarakat. Kehendak masyarakat untuk mengarahkan tingkah laku anggota-anggota masyarakat itu dilakukan dengan membuat pilihan antara tingkah laku yang disetujui dan yang tidak disetjui yang kemudian merupakan norma dalam masyarakat itu. Oleh karena itu, norma hukum itu merupakan persyaratan dari penilaian-penilaian

Pertimbangan tersebut juga dapat dibaca dalam dasar pertimbangan Undang-Undang Republik Indonesia Nomor 2 Tahun 2014 Tentang Perubahan Atas Undang-Undang Nomor 30 Tahun 2004 Tentang Jabatan Notaris, bahwa a. Negara Republik Indonesia sebagai negara hukum berdasarkan Pancasila dan Undang-Undang Dasar Negara Republik Indonesia Tahun 1945 menjamin kepastian, ketertiban, dan perlindungan hukum bagi setiap warga negara; b. bahwa untuk menjamin kepastian, ketertiban, dan perlindungan hukum dibutuhkan alat bukti tertulis yang bersifat autentik mengenai perbuatan, perjanjian, penetapan, dan peristiwa hukum yang dibuat di hadapan atau oleh pejabat yang berwenang; c. bahwa Notaris sebagai pejabat umum yang menjalankan profesi dalam memberikan jasa hukum kepada masyarakat, perlu mendapatkan perlindungan dan jaminan demi tercapainya kepastian hukum.

Pertimbangan dalam UUJN itu jelas menunjukkan, bahwa UUJN dibentuk oleh negara supaya dalam menjalankan profesinya, Notaris dapat memberikan perlindungan hukum bagi setiap warga negara atau siapapun

${ }^{14}$ L.J. Van Apeldoorn, Pengantar Ilmu Hukum, (Jakarta: Djambatan, 1986), hal. 22.

${ }^{15}$ Al-Hilal Hamdi, Menjelajah Dunia Hukum, (Jakarta: LPP-Mpres, 2007), hal. 2. 
yang berurusan dengan jasa layanannya, yang kesemua ini ditujukan demi pemenuhan hak. Adapun untuk menjamin kepastian, ketertiban, dan perlindungan hukum dibutuhkan alat bukti tertulis yang bersifat autentik mengenai perbuatan, perjanjian, penetapan, dan peristiwa hukum yang dibuat di hadapan atau oleh pejabat yang berwenang (Notaris), yang berarti di tangan Notaris, ada HAM harus dilaksanakan. Dalam alat bukti tertulis, jelas disebutkan nama atau identitas, yang diantaranya berurusan dengan hak kepemilikan.

Notaris adalah pejabat umum maksudnya adalah seseorang yang diangkat, diberi wewenang dan kewajiban oleh negara untuk melayani publik dalam hal tertentu. Artinya Notaris merupakan pejabat publik yang menjalankan profesi dalam pelayanan hukum kepada masyarakat, guna memberi perlindungan dan jaminan hukum demi tercapainya kepastian hukum dalam masyarakat. Pejabat umum adalah orang yang menjalankan sebagian fungsi publik negara, yang khususnya di bidang hukum perdata. Dalam ranah ini, bahwa untuk membuat akta otentik, seseorang harus mempunyai kedudukan sebagai "pejabat umum".

Untuk menjalankan peran sebagai penegak HAM itu memang tepat bagi Notaris, karena untuk menjadi Notaris tidaklah mudah. Harus memenuhi sejumlah syarat dan tahapan yang diatur negara. Syarat untuk dapat diangkat menjadi Notaris sebagaimana diatur dalam Pasal 3 UndangUndang No. 30 Tahun 2004 tentang Jabatan Notaris (sudah diubah dengan Undang-undang baru) adalah:

1. Warga negara Indonesia;

2. Bertakwa kepada Tuhan Yang Maha Esa;

3. Berumur paling sedikit 27 tahun;

4. Sehat jasmani dan rohani;

5. Berijazah sarjana hukum dan lulusan jenjang strata dua kenotariatan;

6. Telah menjalani magang atau nyata-nyata telah bekerja sebagai karyawan Notaris dalam waktu 12 bulan berturut-turut pada kantor Notaris atas prakarsa sendiri atau atas rekomendasi Organisasi Notaris setelah lulus strata dua kenotariatan; dan 
7. Tidak berstatus sebagai pegawai negeri, pejabat negara, advokat, atau tidak sedang memangku jabatan lain yang oleh UndangUndang dilarang untuk dirangkap dengan jabatan Notaris.

Setelah menjadi Notaris, peran yang harus dilakukannya tidaklah ringan, karena ia harus berurusan dengan kewenangan, kewajiban, atau tugas-tugas sebagaimana digariskan oleh norma hukum. Ia (Notaris) harus membuat hukum atau tatatan yang tida hidup menjadi hidup (tegak), sehingga dalam kaitannya dengan implementasi norma, ia secara langsung atau tidak langsung menjadi bagian dari penegakan hukum. Penegakan hukum adalah proses dilakukannya upaya untuk tegaknya atau berfungsinya norma-norma hukum secara nyata sebagai pedoman perilaku dalam lalulintas atau hubungan hukum dalam kehidupan bermasyarakat dan bernegara. Ditinjau darui sudut subyeknya, penegakan hukum itu dapat dilakukan oleh subyek yang luas dan dapat pula diartikan sebagai upaya penegakan hukum itu melibatkan semua subyek hukum dalam setiap hubungan hukum. Siapa saja yang menjalankan aturan normatif atau melakukan sesuatu atau tidak melakukan sesuatu dengan mendasarkan diri pada norma aturan hukum yang berlaku, berarti dia menjalankan atau menegakkan aturan hukum. Dalam arti sempit, dari segi subyeknya itu, penegakan hukum itu hanya diartikan sebagai upaya aparatur penegakan hukum tertentu untuk menjamin dan memastikan tegaknya hukum itu, apabila diperlukan, aparatur penegak hukum itu diperkenankan untuk menggunakan daya paksa. ${ }^{16}$

Peran Notaris dalam kaitannya dengan penegakan hukum (HAM) dapat terbaca dalam pemikiran Jimly Ashiddiqy. Jimly Ashiddiqy jmenyebut, bahwa penegakan hukum itu dapat pula ditinjau dari sudut objeknya, yaitu dari segi hukumnya. Dalam hal ini, pengertiannya juga mencakup makna yang luas dan sempit. Dalam arti luas, penegakan hukum itu mencakup pula nilai-nilai keadilan yang terkandung di dalamnya bunyi aturan formal maupun nilai-nilai keadilan yang hidup dalam masyarakat. Tetapi, dalam makna sempit, penegakan hukum itu hanya menyangkut penegakan peraturan yang formal dan tertulis saja. Karena itu, penerjemahan perkataan 'law enforcement' ke dalam bahasa Indonesia dalam menggunakan perkataan 'penegakan hukum' dalam arti luas dan dapat pula digunakan istilah 'penegakan peraturan' dalam arti sempit. Pembedaan antara formalitas aturan hukum yang tertulis dengan cakupan nilai keadilan yang dikandungnya ini bahkan juga timbul dalam bahasa

${ }^{16} \mathrm{http}$ //ayub.staff.hukum.uns.ac.id/artikel-artikel/hukuman-mati-menurutperspektif-ham-internasional/, akses 15 Juli 2019. 
Inggris sendiri dengan dikembangkannya istilah 'the rule of law' versus 'the rule of just law' atau dalam istilah 'the rule of law and not of man' versus istilah 'the rule by law' yang berarti 'the rule of man by law'. Dalam istilah 'the rule of law' terkandung makna pemerintahan oleh hukum, tetapi bukan dalam artinya yang formal, melainkan mencakup pula nilai-nilai keadilan yang terkandung di dalamnya. Karena itu, digunakan istilah 'the rule of just law'. Dalam istilah 'the rule of law and not of man' dimaksudkan untuk menegaskan bahwa pada hakikatnya pemerintahan suatu negara hukum modern itu dilakukan oleh hukum, bukan oleh orang. Istilah sebaliknya adalah 'the rule by law' yang dimaksudkan sebagai pemerintahan oleh orang yang menggunakan hukum sekedar sebagai alat kekuasaan belaka. ${ }^{17}$

Penegakan hukum yang dijalankan oleh Notaris itu dapat diinterpretasikan sebagai penegakan HAM. Setiap pembelajar atau praktisi hukum tentulah memahami, bahwa dalam norma-norma yuridis itu substansinya mengatur soal kewajiban atau hak seseorang atau pihah-pihak dalam masyarakat, baik yang berkaitan dengan kepentingan privat maupun publik. Ketika Notaris tegas dalam menjalankan peran profetisnya, maka otomatis apa yang dilakukannya ini identik dengan menjunjung tinggi atau menghormati HAM.

Notaris merupakan salah satu pelayan masyarakat yang penting atau bahkan istimewa. Pelayanannya ini berhubungan dengan perlindungan atau penegakan hukum. Di tangan Notaris, banyak kepentinga masyarakat bisa terpenuhi atau terlindungi. Hal ini tentu saja terwujug jika Notaris kuat, tegas, dan kokoh dalam menjalankan perintah norma-norma yuridis.

\section{KESIMPULAN}

Negara sudah memberikan kepercayan yang besar pada notaris. Melalui landasan norma yuridis (UUJN), Notaris diberi kewajiban, tugas, dan kewenangan strategis dalam kaitannya dengan pembuatan akta autentik. Hal ini menunukkan, bahwa Notaris merupakan salah satu pelayan masyarakat yang penting atau bahkan istimewa. Pelayanannya ini berhubungan dengan perlindungan atau penegakan hukum. Dalam ranah demikian, peran yang dilakukan oleh Notaris identik dengan menegakkan hak asasi manusia (HAM), karena dari aktifitas yang dilakukannya dapat memberikan jaminan kepastian yuridis terdapa hak-hak masyarakat atau pihak yang meminta jasa layanan kepadanya.

${ }^{17}$ Jimly Ashiddiqy, Penegakan Hukum, http://www.jimly.com/ makalah/namafile / 56/Penegakan_Hukum.pdf, askes 15 Juli 2019. 
Kalau jasa layanan yang ditunjukkannya benar sesuai dengan norma yuridis, maka hal ini memosisikannya sebagai subyek yang bekomitmen terhadap HAM.kehadiran konsumen atau pihak penghadap kepada Notaris merupakan tuntutan baginya untuk memberikan layanan hukum yang tepat, cermat, obyektif, dan egalitarian, atau pemenuhan (peegakan) hak-hak asasi masyarakat (penghadap).

\section{DAFTAR PUSTAKA}

\section{Buku}

Abdul Wahid, 2017, Ana Rokhmatussa'diyah, Anang Sulistyono, Desperatus Perlindungan HAM, Jakarta: Nirmana Media.

Abdul Wahid, Sunardi, Mariyadi, 2017, Penegakan Kode Etik Profesi Notaris. Jakarta: Nirmana Media.

Ahmadi Saleh, 2014, Menjaga Martabat Profesi Hukum, Bandung: Cerdas Ilmu.

Al-Hilal Hamdi, 2007, Menjelajah Dunia Hukum, Jakarta: LPP-Mpres.

CST. Kansil, 2000, Pengantar Hukum dan Tata Hukum Indonesia, Jakarta:

Djambatan.

DPD-Universitas Brawijaya, 2009, penelitian “Konstruksi Perwakilan

Daerah Dalam Sistem Ketatanegaraan Indonesia”, Kerjasama DPD

RI dan Universitas Brawijaya,, (Malang, Pusat Pengkajian

Konstitusi Fakultas Hukum Universitas Brawijaya.

Ensiklopedi Nasional Indonesia, 2004, Jakarta: Delta Pamungkas

G.H.S. Lumban Tobing, 1980, Peraturan Jabatan Notaris (Notaris

Reglement), Jakarta: Erlangga.

L.J. Van Apeldoorn, 1986, Pengantar Ilmu Hukum, Jakarta: Djambatan.

Nusyirwan, 2000, Membedah Profesi Notaris, Bandung: Universitas

Padjadjaran Bandung.

\section{Internet}

Ahmad Zainuri, Gorontalo Butuh Regulasi Kos-kosan, http://www.kompasiana.c, om/ahmad_zaenuri/gorontalo-butuhregulasi-kos-kosan_54f34caa7455139f2b6c6f95, akses 15 Juli 2019. http://ayub.staff.hukum.uns.ac.id/artikel-artikel/hukuman-mati-menurutperspektif-ham-internasional/, akses 15 Juli 2019.

Jimly Ashiddiqy, Penegakan Hukum, http://www.jimly.com/ makalah/namafile / 56/Penegakan_Hukum.pdf, askes 15 Juli 2019. 